\title{
Service Recovery and Its Effect on Students' Satisfaction, Trust, and WOM Communication
}

\author{
Soni Harsono \\ Departement of Management STIE Perbanas Surabaya, Indonesia
}

\begin{tabular}{|c|c|}
\hline ARTICLE INFO & A B S T R A C T \\
\hline $\begin{array}{l}\text { Keywords: } \\
\text { Service recovery, } \\
\text { Satisfaction, } \\
\text { Trust and Word of mouth (WOM) }\end{array}$ & $\begin{array}{l}\text { Service failure is often inevitable; it affects the levels of satisfaction, } \\
\text { trust, and WOM. The purpose of this study is to examine the effect } \\
\text { of service recovery, by using distributive, procedural, and interactional } \\
\text { justice approaches, on students' satisfaction, trust, and WOM } \\
\text { communication at different categories of private universities in East } \\
\text { Java. The population is private universities classified in different levels } \\
\text { of categories: excellent category, flagship category, and Non-flagship } \\
\text { category. The unit analysis is } 80-81 \text { students for each university; } \\
\text { its total sample is } 242 \text { students. Sampling by using an accidental } \\
\text { sampling technique, which is based on coincidence. Data analysis } \\
\text { using regression assisted by SPSS and WarpPLS program. The results } \\
\text { of this study provide university managers in the deep understanding } \\
\text { for that service recovery should always be the focus of attention. It is } \\
\text { provided that service recovery has an insignificant effect either directly } \\
\text { or indirectly on satisfaction, trust, and word of mouth. }\end{array}$ \\
\hline
\end{tabular}

\section{SARI PATI}

Kegagalan layanan acap kali tidak bisa terelakan dan berdampak pada ketidakpuasan, kepercayaan dan word of mouth. Tujuan penelitian ini adalah meneliti secara mendalam dampak pemulihan layanan dengan pendekatan keadilan: distributif, prosedural dan interaksional terhadap kepuasan, kepercayaan dan word of mouth mahasiswa Perguruan Tinggi kategori berbeda di Jawa Timur. Populasi penelitian ini perguruan tinggi swasta dan sampelnya adalah perguruan tinggi dengan kategori universitas yaitu: Unggul, Unggulan dan Non Kategori. Unit analisis adalah mahasiswa berjumlah antara 80-81 masing-masing universitas dan total sampel sebanyak 242 mahasiswa. Menggunakan teknik accidental sampling. Analisis data menggunanan regresi dibantu program SPSS dan WarpPLS. Hasil penelitian memberikan 
pemahaman yang mendalam bagi pengelola perguruan tinggi dimana pemulihan layanan kepada mahasiswa selalu menjadi fokus perhatian, terbukti pada dua universitas berpengaruh tidak signifikan baik langsung maupun tidak langsung kepada kepuasan, kepercayaan dan word of mouth.

(C) 2018 IRJBS, All rights reserved.

\section{INTRODUCTION}

In Indonesia, there is a proverb which says "cheap in the mouth but expensive on the scales". This proverb describes a person who likes to make promises, but he never keeps them. This proverb is often found in daily life, such as in interaction between individuals, interaction between institutions or organizations, and interaction between institution / organization and individual, either in social or in business activities. In the midst of intense business competition, promises are often deliberately made to attract customers to buy a product. Intense competition not only also takes place in the world of business, but also in the world of education, especially among private universities in Indonesia. Competition has created creative and innovative breakthroughs. Creativity and innovation in academic field, service, and administrative processes need to be communicated to stakeholders with the aim to raise the image of the universities. In practice, however, everything that has been communicated or informed is often contrary to the fact or reality. The educational regulation improved by the government is expected to create satisfaction to stakeholders, especially students.

Some issues in the management of universities in Indonesia include the existence of original but fake diploma, the implementation of long distance education, the excess student quota, etc. Ministry of Research and Technology and Higher
Education will take action against the universities that commit such offenses. Source: https://www. kemenkopmk.go.id/artikel/menristek-dan-diktitindak-perguruan-tinggi-yang-terima-mahasiswamelebihi-kuota. Downloaded on Tuesday, February 21, 2017, at 9:30.

Complaints about facilities, educational services, as well as extension programs at XXX University are allegedly caused by irregularities in the management and use of funds available at the university. In addition, there are other eight points of complaints aimed at the XXX University. Source: https://www.lapor.go.id/id/1106547/keluhan-fasilitas-pelayanan-pendidikan-dan-program-sarjanaekstensi-di-universitas-jambi.htm. Downloaded on Tuesday, February 21, 2017, at 09.35.

There was a protest against campus policy. Thousands of students of XXY University rallied to protest the policy of the rector. During the demonstration, the students brought a coffin as a sign of their concern about the planned dissolution of the Student Executive Board (BEM) by the rector. Source: http://bintan.batamtoday. com/berita53110-Protes-Kebijakan-Kampus,Mahasiswa-UPB-Berunjuk-Rasa-Bawa-Keranda. html. Downloaded on Tuesday, February 21, 2017, at 09.50 .

The students of YZ University protested against the university's policy of raising the tuition of 15 until 
45 percent. They objected because the increase was charged to the ninth-semester students. The policy of raising the tuition was intended only to students who could not complete their lectures within 4 years or 8 semesters. The university detailed the increase of 15 percent for a five-year study period, 30 percent for a six-year study period and the greatest increase of 45 percent of the initial tuition nominal for a seven-year study period. The policy was applied starting from the tuition payment for the following semester of 2012/2013 school year. Source: http://edukasi.kompas.com/ read/2012/07/26/17404077/SPP.di.Unibraw.Naik.. Mahasiswa.Protes. Downloaded on Tuesday, February 21, 2017, at 10.00

Not all students who are disappointed with academic process and service are willing to express their complaints to their colleges, considering their long-term process on the campus. There is a sense of "threat" if they are too critical of their campus. However, only those who have great interests and expect an improvement on their campus will submit their complaints through appropriate media or channels. They are the students who actually care for and dare to complain to the campus. Such caring students should be treated well rather than hostile. Constructive complaint or criticism should be received, respected and acted upon well.

Service failure in the business world and other activities, particularly due to human error, is frequently unavoidable. The failure to perform such services may lead to customer dissatisfaction. Kana (2001) reveals that customer satisfaction can provide several benefits, such as harmonizing the relationship between organization / company and customer, creating a good foundation for repurchasing, and creating good communication or recommending to others (word-of-mouth) as the foundation of customer loyalty creation.

Empirical evidence suggests that not all disgruntled consumers are willing to convey their complaints to producers or service providers. Research conducted by Singh and Pandya (1991) finds that the disgruntled customers do not convey their complaint to the service provider but to the third party. Dick and Basu (1994) find that consumers move to other products or brands instead. It is also supported by Gustaffson (2009) that when customers get a good service recovery, they tend to perceive a high level of fairness, thus creating a positive attitude and increasing the intention to buy again in the future. On the contrary, those who experience very low service recovery will also perceive low fairness.

Furthermore, Zemke (1999) reveals that a customer who feels dissatisfied, related to his bad experience of a particular service, can influence from 10 to 20 people (consumers and customers) to no longer relate to the service that provides the bad service. Therefore, service recovery is required as a response or responsibility for the poor quality of service that has been provided.

However, complaints are not only because of dissatisfaction but also because of the facts or phenomena seen. Tronvoll (2011) reveals that complaints not only arise as a result of dissatisfaction over the quality of service but also because of what is seen and perceived emotionally when interacting with the service.

Nguyen, Doan T, McColl-Kennedy, Janet R, Dagger, Tracey S (2012) support the argument that customers have different recovery preferences. In addition, customers are satisfied with the service recovery solution only when it matches the most demanding recovery preferences. Customer recovery preferences have a significant impact on customer satisfaction and repurchase.

According to Baker, Thomas and Meyer, Tracy (2014), the visible interaction effect of the most positive outcome is when managers and frontline employees provide a complete explanation of the service failures and indicate the credibility of 
the sources in conveying information. MolinerVelázquez, Beatriz, Ruiz-Molina, María-Eugenia and Fayos-Gardó, Teresa (2015) confirm that the causal relationships and satisfaction recovery efforts using service recovery will, in turn, have a direct effect on the intent of conventional and online WOM. Furthermore, Multi-group analysis reveals that age moderates the relationship between satisfaction and online WOM.

Mattila (2001) reveals that service recovery can be done using several approaches, such as: (1) justice dimensions, which include distributive justice, interactional justice and procedural justice; (2) service failure theory, which can be seen from individual and situational aspects; and (3) customer loyalty.

Some research results on service recovery that are still in debate are: Sing and Pandya (1991) "consumers do not file a complaint directly, but convey it to third parties instead"; Dick and Basu (1994) "consumers instead move on to other products or brands"; Zemke (1999) "consumers do not want to deal with the service; Gustaffson (2009) "consumers perceive low justice"; while Tronvoll (2011) "dissatisfaction impacts on complaints"; Nguyen, et al (2012) "service recovery solution is taken only when it matches the most demanding recovery preferences" and Baker, et al (2014) "service failure indicates the credibility of the source in conveying information". Departing from the results of this study, this study tries to replicate previous research but on different objects, that is, at private universities with different levels of categories.

The aspects that can be useful to improve the quality of education, among others, are improving academic quality, improving services that support the campus activities, and conducting inventory as well as analyzing complaints and critics from students, parents, or the users of the college graduates. The incoming complaints or criticisms are analyzed in depth by competent authority, and the complaints eventually serve as materials for improvements.

The purposes of this research are: (1) to examine the effect of service recovery (using distributive justice, interactional justice and procedural justice approaches) on students' satisfaction, trust and WOM at excellent, flagship and non-flagship private universities; (2) to express and know the students' responses when they get service dissatisfaction; (3) to expose the students' perceptions of service recovery (distributive, procedural and interactional justice) in the field of academic, infrastructure, teaching and learning, and administration related to employees and lecturers.

\section{Theoretical Framework}

Nguyen, Doan T, McColl-Kennedy, Janet R, Dagger, Tracey S (2012) find that customers have different recovery preferences. In addition, customers will be satisfied with the service recovery solution only when it matches the most demanding recovery preferences. Recovery preferences have a significant effect on customer satisfaction and repurchase.

Lin, Hsin-Hui, Wang, Yi-Shun and Chang, Li-Kuan (2011) prove that distributive justice, procedural justice, and interactional justice have a significant positive effect on customer satisfaction. Among the three justice dimensions of service recovery, distributive justice has a significant positive effect on repurchase intention, and only interactional justice that has a significant negative effect on negative WOM. In addition, both the interaction between distributive justice and procedural justice and the interaction between distributive justice and interactional justice are found to have significant effect on customer satisfaction, negative WOM, and repurchase intention.

The results also show that the service recovery paradox does not seem to exist in the retail context. This finding allows online retailers to develop more effective strategies to prevent service failures and 
improve customer satisfaction, negative WOM, and repurchase intentions.

Johnston, Robert and Michel, Stefan (2008) argue that service recovery procedures have a greater impact on employees and improved processes on customers. In addition, many organizations seem to be good or get benefit from the service recovery and recovery procedures. This research has posed challenges on the way some organizations focus on recovery procedures and satisfy customers and pointed out that without performing service recovery, they have lost huge benefits. It also shows that many organizations have a long way to develop service recovery procedures.

Matos, et al (2009) proves that justice, in service recovery, consists of three dimensions: distributive justice (the justice perceived with the existence of compensation provided or offered by the service provider), procedural justice (the justice perceived with the existence of exchange policy), and interactional justice (the way service providers respond to complaints arising from customers).

Furthermore, in study 1, Baker, Thomas and Meyer, Tracy (2014) find that the visible interaction effect shows that the most positive result is when the manager and the front line employee give a full explanation of the service failure. The result of study 2 indicates the credibility of the source in conveying information.

Zhang, Min, Dai, Xujing and He, Zhen (2015) prove that e-retailing needs to pay attention to building an integrated recovery system. This system can facilitate the relationship between employee job satisfaction and OCB, which ultimately affects market performance. However, the relationship between job satisfaction and OCB as well as market performance is found very low in the context of e-retailing in China.

Moliner-Velázquez, Beatriz, Ruiz-Molina, MaríaEugenia and Fayos-Gardó, Teresa (2015) prove that the recovery efforts on satisfaction using service recovery, in turn, has direct effect on the intentions of conventional and online WOM. Furthermore, Multigroup analysis reveals that age moderates the relationship between satisfaction and online WOM.

A company can survive and thrive if it is able to create customer satisfaction. Thus, all efforts must be made in order to create customer satisfaction. Satisfaction is a comparison between perception / expectation and the facts / reality. As stated by Parasuraman et al. (1985), customer expectation is highly dynamic because it can change from one customer to another.

Due to its dynamic nature, each customer has different expectations or perceptions in response or judgment. Zeithaml et al. (1993) reveals that the expectations of customers are standardized and will be compared with experience when consuming or using the actual services. After that they evaluate and compare so that they can conclude and say 'satisfied or dissatisfied'. In line with this statement, Oliver (1980) states that in service setting called confirmation-disconfirmation theory, confirmation occurs if expectation matches the actual performance of the service provider. If the actual performance exceeds the expectation, it can create satisfaction, or in its theory called positive disconfirmation. Conversely, if the actual performance is worse than the expectation, it will create dissatisfaction, or in its theory called negative disconfirmation.

Service failure is one of the factors that create customer dissatisfaction. Whether it is anticipated or not, service failure is often unavoidable. This may be due to human error or non-technical factors. The consequence of the service failure is the emergence of various complaints or criticism from customers. At certain point, the customers will decide no longer buy or connect with the service providers and ultimately, they create a negative Word of Mouth (WOM). For an 
organization, customers who are willing to deliver or inform their complaints should be appreciated. Gilly and Hansen, 1985 in East 2000 state that the complaints delivered by customers provide benefits to organization or company because the organization / company will have the opportunity to address or reduce dissatisfaction, to reduce negative WOM delivered by the customer to others, and to obtain useful market information in order to maintain customers.

Organizations or companies should be able to accept and respond complaints or criticisms from their customers openly. They need to listen and find out the best solution on how to handle and follow up the complaints positively. Thus, it can create service recovery which, in turn, will build trust to the customers.

Service recovery refers to actions taken by service providers to address customer complaints related to the service failures perceived by customer (Gronroos, 1988). In line with that opinion, Lovelock (2001) states that service recovery is an action taken by service providers to resolve complaints resulting from the failure to provide services and to retain customer's goodwill.

There are many forms of service recovery that can be done to overcome service failures, as proposed by (Kelley et al., 1993), such as by paying compensation, providing discounts or rebates, improving service quality, providing free goods or services, and asking for apologies. McDougall and Levesque (2000) also suggest other forms of service recovery, such as by providing tangible compensation and creating a good interaction between service providers and customers to influence customer perceptions of service recovery.

Mattila (2001) explains that service recovery, theoretically, can be done using several approaches, namely: (1) Justice Dimensions, consisting of Distributive Justice (DJ), Procedural
Justice (PJ), and Interactional Justice (IJ); (2) Service Failure Theory, ie individual and situational; and (3) Customer Loyalty.

Similarly, Tax and Brown (2000) point out that distributive justice is the dominant reference in service recovery analysis. Procedural justice focuses on perceived fairness of the policies, procedures, and criteria used by decision makers over disputes or negotiations.

Seider and Berry (1998) reveal that distributive justice can be seen from the decision and allocation of results. The types of distributive justice include rewards to business partners in business transactions, equality for business partners in obtaining the same results, and the needs of each business partner. There are several aspects to consider in procedural justice, namely consistency, unbiased, accuracy, correction, representation and ethics. Furthermore, Seider and Berry (1998) explain that interactional justice has characteristics of interpersonal behavior, such as respect, honest, courteous and professional. Interpersonal behavior is the belief that becomes the core of business transactions. Trust, in this case, becomes a balance of risk and uncertainty of business services in order to maintain customer loyalty.

Oliver (in Margee et al 2008) reveals that customer satisfaction is an attitude resulting from comparisons between expected performance and perceived performance from the service experience. If the performance fails to meet expectations, the customers will be dissatisfied. If the performance is in line with the expectation, the customers will be satisfied. If the performance exceeds the expectations, the customers will be very satisfied or happy.

Kotler and Keller (2009) define that satisfaction is the pleasure or disappointment perceived by customers after comparing between the performance of the product thought and the 
performance of the results expected. If the performance meets the perceived quality, there will be likely customer satisfaction. A high level of satisfaction can create an emotional bond between the customer and the company.

Satisfaction and dissatisfaction with the product will affect consumer behavior in the future. If satisfied, the consumers will show a higher possibility to re-purchase the product and also tend to tell the positive sides of the brand to others. If dissatisfied, the consumers may discard or return the product. They may take public action, such as filing a complaint to the company, going to a lawyer, or complaining to another group (such as a business, private or government agency). Personal action may be in decision to stop buying the product or to warn friends. One of the post-purchase behaviors is word of mouth recommendation.

Word of mouth recommendations are usually accepted quickly by consumers because those who deliver them are credible, such as experts, friends, family, and media publications. Lovelock and Wright (2007) explain that recommendations from other consumers are generally viewed as more reliable than the information activities undertaken by a company and can have a strong influence on people's decisions to use or avoid a service. Information from word of mouth even often occurs when the transaction is taking place. When consumers talk to each other about some aspects of the service, this information can affect both their behavior and their satisfaction with the service.

A study conducted by Hennig-Thurau, Langer, Hansen (2001), which focuses on higher education, proves that the student's trust to higher education institution also affects the student's loyalty. Therefore, the students who have trust to higher education institution will be willing to convey positive things about the institution and to recommend the institution to others.

\section{METHODS}

This research belongs to explanatory research which aims to examine and explain causal relationships partially and simultaneously between service recovery variables (distributive justice/DJ, procedural justice/PJ, interactional justice/IJ) towards satisfaction (S), trust (T), word of mouth (WOM) through hypothesis testing. The population in this study is private universities in East Java which are classified in different levels of categories: UM (excellent category), UKP (flagship category), and UTGS (Non-flagship category). The analysis unit in this study is 80-81 students for each university, or with the total sample of 242 students. Sampling is conducted by using accidental sampling technique, a sampling technique which is based on coincidence.

The independent variables in this research are distributive justice $\left(\mathrm{X}_{1}\right)$, procedural justice $\left(\mathrm{X}_{2}\right)$ and interactional justice $\left(\mathrm{X}_{3}\right)$. The intervening variable is satisfaction (Z). And the dependent variables are trust $\left(\mathrm{Y}_{1}\right)$, and word of mouth $\left(\mathrm{Y}_{2}\right)$.

Perceived justice is defined as the opinion of respondents to the fairness of service acceptance, treatment, and service process on the handling of the complaints they convey. Satisfaction is defined as the opinion of respondents to the feelings of pleasure or disappointment that arise because comparing between the actual performance and their expectations. Trust is defined as the opinion of the respondents to the private university, whether it can be trusted or relied upon in fulfilling its promise. Word of mouth is defined as the opinion of the respondents who are willing to give recommendation related to the private university service he felt to others.

The independent and dependent variables are measured using Likert scale. This scale is used to measure the respondents' responses to the research object with a weight value of one to five, that is, from strongly disagree to strongly agree. 
Data collection in this study is conducted by using questionnaires and interviews with the aim to obtain information directly from respondents to complete the things required in this research.

Validity test of the instrument is done using face validity, or using expert judgment. In this case, the instrument is constructed based on the aspects that will be measured using a particular theory. Next, validity test is done using SPSS program and the analysis technique is done using Bivariate Pearson correlation (Product Moment Pearson), in which the loading value above 0.50 is considered valid. Reliability test is done using SPSS program, and the analysis technique is done by looking at the value of Cronbach's Alpha.

The conceptual framework is structured to explain which variables serve as independent variables and dependent variables.

Data analysis in this research uses regression assisted by WarpPLS program. Sholihin and Ratmono (2013) reveal that WarpPLS program can identify non-linear relationships between latent variables and correct the coefficient value of the paths based on those relationships. Therefore, the program is named Warp which means curvature. Since most relationships between variables are non-linear, WarpPLS can find real relationships between latent variables in SEM analysis.

Some other advantages of the WarpPLS program are:

a. able to provide illustrations of nonlinear relationships in the form of scatter plots.

b. able to estimate $p$ value of path coefficient automatically. Most other PLS software only gives the $\mathrm{T}$ value, so users should compare it to the $\mathrm{T}$ table or look for its $\mathrm{p}$ value.

c. able to provide some indicators of the fit model that can be useful to compare the best models among different models. The resulting fit indicators include average R-square (ARS), average path coefficient (APC) and average variance inflation factor (AVIF). There is no other PLS software that can provide the fit indicators.

d. able to provide the coefficient and p value for moderation model directly, and there are some other advantages.

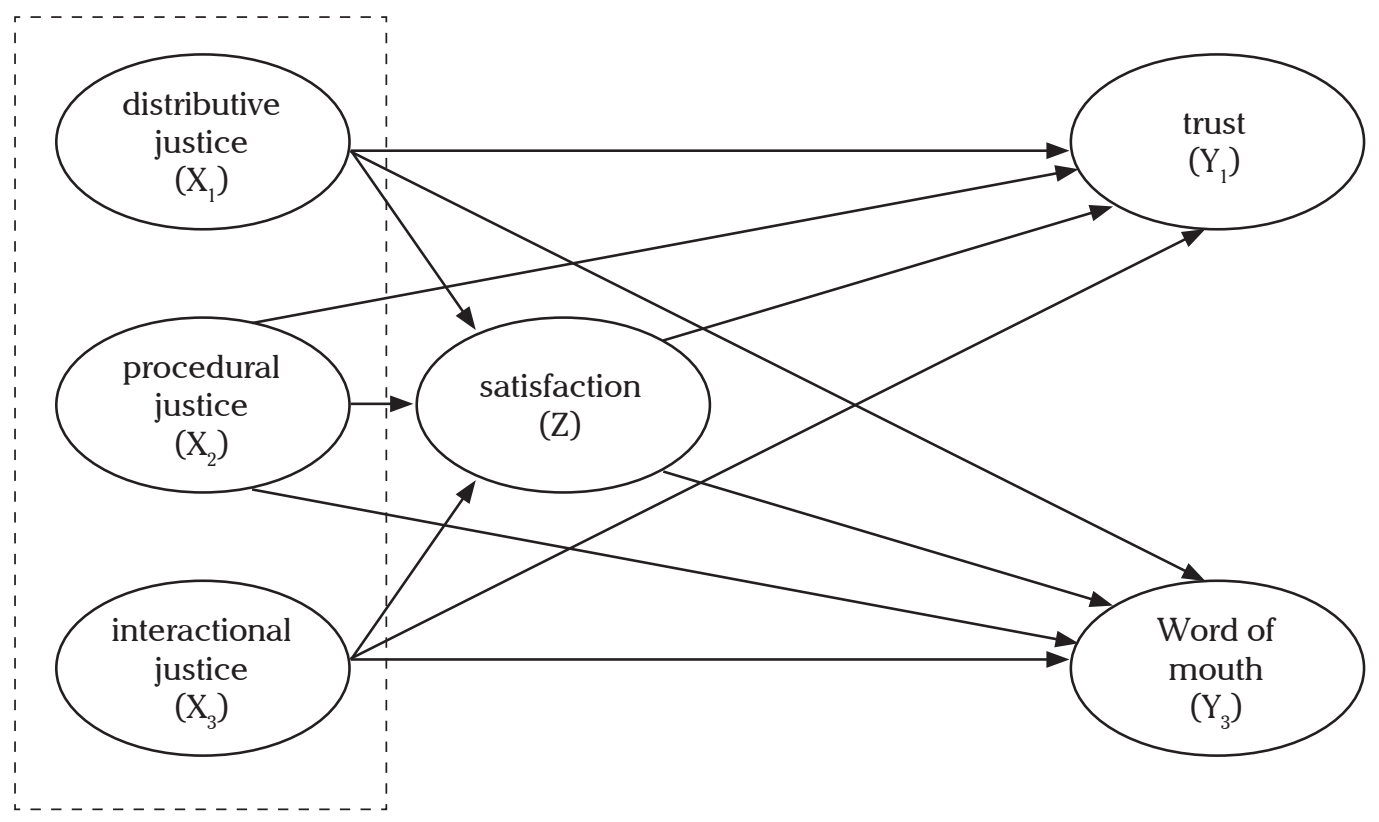

Figure 1. Conceptual framework 


\section{RESULTS AND DISCUSSION}

The description of respondents' characteristics for excellent university category are shown in Table 1.

Based on Table 1, of the 81 respondents, 34 are men (39\%) and 47 are women (61\%). Based on the age of respondents: $<18$ to 18 years old = $0(0 \%), 19$ years old $=3(4 \%), 20$ years old $=18$ $(22 \%), 21$ years old $=48(59 \%)$ and $>21$ years old $=12(15 \%)$. Based on the domicile of respondents: living permanently in Surabaya and Sidoarjo $=0$ $(0 \%)$, in Gresik $=3(4 \%)$, in Mojokerto $=18(22 \%)$, in Pasuruan 48 (59\%), and in other regions = 12 (15\%).

Based on the origin of the school: from Senior High School = 54 (67\%); from Vocational School $=9(11 \%)$, from Madrasah (Islamic School) $=10$ $(12 \%)$, and from other schools $=8(10 \%)$. Based on the respondent's parent's job: SOE's employee = $2(2 \%)$, private employee $=13(16 \%)$, civil servant $=21(26 \%)$, army $/$ police $=4(5 \%)$, pensioner $=1$ $(1 \%)$; self-employed $=35$ (43\%), others $=5(6 \%)$.

Based on the income of respondent's parent, 76 respondents filled in the income column but 5 respondents did not. Of the 76 respondents: the income of $1-1.9$ million per month $=17(22 \%)$, $2-2.9$ million $=13(16 \%), 3-3.9$ million $=20$ $(25 \%) ; 4-4.9$ million $=10(12 \%), 5-5.9$ million $=$ 4 (5\%), 6 - 6.9 million $=3(4 \%)$, and 7 million per month $=7(8.5 \%)$, respondents who did not fill in the column $=7$ (8.5\%). Based on the respondent ambition after graduation, 78 respondents filled in the student ambition column but 3 respondents did not. Working as civil servant $=5(6 \%)$, working in SOEs / Private companies = 28 (35\%), becoming entrepreneur $=26(32 \%)$, working in bank $=14$ (17\%) and others 5 (6\%), and the respondents who did not fill in the column $=3(4 \%)$.

Based on the way to get information on the university, of the 81 respondents, 86 filled in the university information column, which means that a respondent may know his university information from two or more sources. Information from TV / Radio $=6(7 \%)$, from WEB of the university $=$ $31(36 \%)$, from parents $=9(10 \%)$, from friends $=$ 13 (15\%), from the senior high school teacher $=2$ $(2 \%)$, from university brochures $=14(16 \%)$ and from other sources $=11(13 \%)$.

Based on the complaint to the campus, a respondent can express more than one type of complaint. The types of complaints: learning process $=3(3 \%)$, parking $=45(45 \%)$, library $=4$ $(4 \%)$, academic $=6(6 \%)$, finance $=3(3 \%)$, general affair $=5(5 \%)$, WIFI $=20(20 \%)$, department $=$ $1(1 \%)$, academic advisor $=3(3 \%)$ and room cleanliness $=10(10 \%)$.

Based on the media used by respondents to convey complaints: facing directly to the leaders $=5(6 \%)$, via telephone $=3(3 \%)$, via e-mail $=64(74 \%)$, direct mail $=12(14 \%)$, and via SMS $=2(2 \%)$. Based on to whom the complaint is addressed: the leader of university $=6(7 \%)$, section head $=8$ $(10 \%)$, and employees $=67(83 \%)$.

The validity test of instruments in this research was conducted using the expert judgment after the aspects of instrument measured had been constructed. Validity test was done using Bivariate Pearson correlation (Product Moment Pearson). From the results of calculation, it is obtained that all items/indicators of the variables of distributive justice, procedural justice, interactional justice, satisfaction, trust and WOM are declared "valid". Reliability test was done by looking at the value of Cronbach's Alpha. The Cronbach's Alpha value of each variable is from 0.668 (the lowest value) to 0.834 (the highest value). Thus, it can be concluded that all variables are declared "reliable".

Based on Table 2, it can be seen that the variable of distributive justice (DJ), for the excellent university (UMM) and the flagship university (UKP), is in the category of "agree" (4.104 and 3.606), but, for the non-flagship university (UTGS), is in the category of "doubtful" (3.109). The variable of 
Table 1. Summary of the Characteristics of Respondents from UMM (excellent university category)

\begin{tabular}{|c|c|c|c|c|c|c|c|c|}
\hline \multicolumn{9}{|c|}{ gender, age and domicile of respondents living permanently } \\
\hline \multicolumn{3}{|c|}{ Gender } & \multicolumn{3}{|c|}{ Age } & \multicolumn{3}{|c|}{$\begin{array}{l}\text { domicile of respondents living } \\
\text { permanently in }\end{array}$} \\
\hline Man & 34 & $42 \%$ & $<18$ years old & 0 & $0 \%$ & $\begin{array}{l}\text { Surabaya and } \\
\text { Sidoarjo }\end{array}$ & 0 & $0 \%$ \\
\hline \multirow[t]{5}{*}{ Woman } & 47 & $58 \%$ & 18 years old & 0 & $0 \%$ & Gresik & 3 & $4 \%$ \\
\hline & & & 19 years old & 3 & $4 \%$ & Mojokerto & 18 & $22 \%$ \\
\hline & & & 20 years old & 18 & $22 \%$ & Pasuruan & 48 & $59 \%$ \\
\hline & & & 21years old & 48 & $59 \%$ & Others regions & 12 & $15 \%$ \\
\hline & & & $>21$ years old & 12 & $15 \%$ & & & \\
\hline Total & 81 & $100 \%$ & Total & 81 & $100 \%$ & Total & 81 & $100 \%$ \\
\hline \multicolumn{9}{|c|}{ origin of the school, parent's job and income of respondent's parent } \\
\hline \multicolumn{3}{|c|}{ origin of the school } & \multicolumn{3}{|c|}{ parent's job } & \multicolumn{3}{|c|}{$\begin{array}{c}\text { income of respondent's parent/per } \\
\text { month }\end{array}$} \\
\hline $\begin{array}{l}\text { Senior High } \\
\text { School }\end{array}$ & 54 & $67 \%$ & SOE's Employee & 2 & $2 \%$ & $1-1.9$ million & 17 & $21 \%$ \\
\hline $\begin{array}{l}\text { Vocational } \\
\text { School }\end{array}$ & 9 & $11 \%$ & $\begin{array}{l}\text { Private } \\
\text { Employee }\end{array}$ & 13 & $16 \%$ & 2 - 2.9 million & 13 & $16 \%$ \\
\hline $\begin{array}{l}\text { Madrasah } \\
\text { (Islamic School) }\end{array}$ & 10 & $12 \%$ & Civil Servant & 21 & $26 \%$ & 3 - 3.9 million & 20 & $25 \%$ \\
\hline \multirow[t]{5}{*}{ other schools } & 8 & $10 \%$ & Army / Police & 4 & $5 \%$ & $4-4.9$ million & 10 & $12 \%$ \\
\hline & & & Pensioner & 1 & $1 \%$ & 5 - 5.9 million & 4 & $5 \%$ \\
\hline & & & Self-employed & 35 & $43 \%$ & 6 - 6.9 million & 3 & $4 \%$ \\
\hline & & & Pensioner & 1 & $1 \%$ & 7 million per month & 7 & $8.5 \%$ \\
\hline & & & Others & 4 & $6 \%$ & respondents did not & 7 & $8.5 \%$ \\
\hline Total & 81 & $100 \%$ & Total & 81 & $100 \%$ & Total & 81 & $100 \%$ \\
\hline \multicolumn{9}{|c|}{ Ambition after graduation, information on the university and complaint to the campus } \\
\hline \multicolumn{3}{|c|}{ ambition after graduation } & \multicolumn{3}{|c|}{ information on the university } & \multicolumn{3}{|c|}{ complaint to the campus* } \\
\hline $\begin{array}{l}\text { Working as civil } \\
\text { servant }\end{array}$ & 5 & $6 \%$ & TV / Radio & 6 & $7 \%$ & learning process & 3 & $3 \%$ \\
\hline $\begin{array}{l}\text { working in } \\
\text { SOEs / Private } \\
\text { companies }\end{array}$ & 28 & $35 \%$ & $\begin{array}{l}\text { Senior High } \\
\text { School Teacher }\end{array}$ & 2 & $2 \%$ & parking & 45 & $45 \%$ \\
\hline entrepreneur & 26 & $32 \%$ & $\begin{array}{l}\text { University } \\
\text { Brochures }\end{array}$ & 14 & $16 \%$ & library & 4 & $4 \%$ \\
\hline working in bank & 14 & $17 \%$ & Other Sources & 9 & $13 \%$ & academic & 6 & $6 \%$ \\
\hline Others & 5 & $6 \%$ & $\begin{array}{l}\text { WEB of the } \\
\text { University }\end{array}$ & 31 & $36 \%$ & Finance & 3 & $3 \%$ \\
\hline \multirow[t]{5}{*}{ Did not } & 3 & $4 \%$ & Parents & 9 & $10 \%$ & general affair & 5 & $5 \%$ \\
\hline & & & Friends & 10 & $11 \%$ & WIFI & 20 & $20 \%$ \\
\hline & & & & & & department & 1 & $1 \%$ \\
\hline & & & & & & academic adviso & 3 & $3 \%$ \\
\hline & & & & & & room cleanliness & 10 & $10 \%$ \\
\hline Total & 81 & $100 \%$ & Total & 81 & $100 \%$ & Total & 100 & $100 \%$ \\
\hline \multicolumn{9}{|c|}{ media used by respondents to convey complaints } \\
\hline $\begin{array}{r}\text { media used by } r \\
\text { convey cor }\end{array}$ & resp & $\begin{array}{l}\text { lents to } \\
S^{*}\end{array}$ & $\begin{array}{r}\text { to whom the } \\
\text { addre }\end{array}$ & $\begin{array}{l}\text { comp } \\
\text { ssed }\end{array}$ & int is & & & \\
\hline $\begin{array}{l}\text { facing directly to } \\
\text { the leaders }\end{array}$ & 5 & $6 \%$ & $\begin{array}{l}\text { Leader of } \\
\text { University }\end{array}$ & 6 & $7 \%$ & & & \\
\hline via telephone & 3 & $3 \%$ & Section Head & 8 & $10 \%$ & & & \\
\hline e-mail & 64 & $74 \%$ & Employees & 67 & $83 \%$ & & & \\
\hline direct mail & 12 & $14 \%$ & & & & & & \\
\hline SMS & 2 & $2 \%$ & & & & & & \\
\hline Total & 86 & $100 \%$ & Total & 81 & $100 \%$ & & & \\
\hline
\end{tabular}


Table 2. Respondents' Responses to the Variables of Distributive Justice (DJ), Procedural Justice (PJ) and Interactional Justice (IJ): Satisfaction (S), Trust (T) and WOM

\begin{tabular}{|c|c|c|c|c|c|c|}
\hline \multirow{2}{*}{$\begin{array}{c}\text { Variable } \\
\text { Distributive Justice (DJ) }\end{array}$} & \multicolumn{2}{|c|}{ UMM (Excellent) } & \multicolumn{2}{|c|}{ UKP (Flagship) } & \multicolumn{2}{|c|}{ UTGS (Non-flagship) } \\
\hline & Mean & Category & Mean & Category & Mean & Category \\
\hline DJ1 & 4.098 & Agree & 3.575 & Agree & 3.1 & Doubtful \\
\hline DJ2 & 4.172 & Agree & 3.625 & Agree & 3.187 & Doubtful \\
\hline DJ3 & 4.012 & Agree & 3.587 & Agree & 3 & Doubtful \\
\hline DJ4 & 4.135 & Agree & 3.637 & Agree & 3.15 & Doubtful \\
\hline Mean of DJ & 4.104 & Agree & 3.606 & Agree & 3.109 & Doubtful \\
\hline PJ1 & 2.518 & Disagree & 2.812 & Doubtful & 2.887 & Doubtful \\
\hline PJ2 & 2.259 & Disagree & 2.9 & Doubtful & 3.325 & Doubtful \\
\hline PJ3 & 2.456 & Disagree & 2.987 & Doubtful & 3.725 & Agree \\
\hline PJ4 & 3.901 & Agree & 3.362 & Doubtful & 2.737 & Doubtful \\
\hline PJ5 & 2.012 & Disagree & 3.162 & Doubtful & 3.425 & Agree \\
\hline PJ6 & 4.037 & Agree & 3.387 & Doubtful & 2.75 & Doubtful \\
\hline PJ7 & 3.506 & Agree & 3.287 & Doubtful & 2.337 & Disagree \\
\hline PJ8 & 3.506 & Agree & 3.225 & Doubtful & 2.5 & Disagree \\
\hline Mean of PJ & 3.024 & Doubtful & 3.140 & Doubtful & 2.960 & Doubtful \\
\hline IJ1 & 3.753 & Agree & 3.412 & Agree & 2.95 & Doubtful \\
\hline IJ2 & 3.716 & Agree & 3.462 & Agree & 3.075 & Doubtful \\
\hline IJ3 & 4.012 & Agree & 3.45 & Agree & 3.05 & Doubtful \\
\hline IJ4 & 3.987 & Agree & 3.525 & Agree & 3.125 & Doubtful \\
\hline Mean of IJ & 3.867 & Agree & 3.462 & Agree & 3.05 & Doubtful \\
\hline \multicolumn{7}{|l|}{ Satisfaction } \\
\hline S1 & 4.18 & Satisfied & 3.775 & Satisfied & 3.662 & Satisfied \\
\hline $\mathrm{S} 2$ & 4.25 & Strongly satisfied & 3.525 & Satisfied & 3.375 & Doubtful \\
\hline S3 & 4.32 & Strongly satisfied & 4.074 & Satisfied & 3.562 & Satisfied \\
\hline S4 & 4.19 & Satisfied & 3.812 & Satisfied & 2.386 & Dissatisfied \\
\hline S5 & 4.2 & Satisfied & 3.887 & Satisfied & 2.5 & Dissatisfied \\
\hline S6 & 4.03 & Satisfied & 3.15 & Doubtful & 2.575 & Dissatisfied \\
\hline S7 & 4.04 & Satisfied & 3.587 & Satisfied & 3.025 & Doubtful \\
\hline S8 & 4.34 & Strongly Satisfied & 3.8 & Satisfied & 3.35 & Doubtful \\
\hline S9 & 4.04 & Satisfied & 2.35 & Dissatisfied & 3.45 & Satisfied \\
\hline $\mathrm{S} 10$ & 4.27 & Satisfied & 3.512 & Satisfied & 3.725 & Satisfied \\
\hline S11 & 4.08 & Satisfied & 3.9 & Satisfied & 3.812 & Satisfied \\
\hline Mean of S & 4.176 & Satisfied & 3.579 & Satisfied & 3.220 & Doubtful \\
\hline \multicolumn{7}{|l|}{ Trust } \\
\hline $\mathrm{T} 1$ & 4.246 & Strongly agree & 3.737 & Agree & 3.262 & Doubtful \\
\hline $\mathrm{T} 2$ & 4.419 & Strongly agree & 4.012 & Agree & 4.037 & Agree \\
\hline T3* & 1.53 & Strongly disagree & 2.4 & Disagree & 2.587 & Disagree \\
\hline Mean of T & 3.398 & Agree & 3.383 & Doubtful & 3.295 & Doubtful \\
\hline \multicolumn{7}{|l|}{ WOM } \\
\hline WOM1 & 4.641 & Strongly agree & 3.762 & Agree & 3.987 & Agree \\
\hline WOM2 & 1.432 & Strongly disagree & 2.625 & Disagree & 2.975 & Doubtful \\
\hline WOM3 & 4.691 & Strongly agree & 3.675 & Agree & 3.8 & Agree \\
\hline WOM4 & 4.567 & Strongly agree & 3.712 & Agree & 3.925 & Agree \\
\hline Mean of WOM & 3.837 & Agree & 3.436 & Agree & 3.671 & Agree \\
\hline
\end{tabular}

Source: Research result 
procedural justice (PJ), for all universities, is in the category of "doubtful" (3.024; 3.140 and 2.960). Furthermore, the variable of interactional justice (IJ), for the excellent university (UMM) and the flagship university (UKP), is in the category of "agree" (3.867 and 3.462), but, for the non-flagship university, is in the category of "doubtful" (3.05).

It can be seen that the variable of satisfaction, for the excellent and flagship universities, is in the category of "satisfied" (4.176 and 3.579), but, for the non-flagship university, is in the category of "doubtful" (3.220). The variable of trust, for the excellent university, is the category of "agree" (3.398), but, for flagship and non-flagship universities is in the category of "doubtful" $(3,383$ and 3,295). Finally, the variable of WOM, for all categories of universities, is in the category of "agree" (3.837, 3.436 and 3.671).

Figure 2 shows the results of the analysis done at university with excellent category.

Figure 2 shows the partial influence of distributive, procedural and interactional justice on satisfaction, trust and WOM for service recovery at university with excellent category. Distributive justice has a significant positive effect on satisfaction (coefficient $=\beta=0.51 ; \rho<0.01$ ), procedural justice has a significant negative effect on satisfaction (coefficient $=\beta=-0.40 ; \rho<0.01$ ), but interactional justice has an insignificant effect on satisfaction (coefficient $=\beta=0.08 ; \rho=0.23$ ). Furthermore, distributive justice has a significant positive effect on trust (coefficient $=\beta=0.25, \rho<$ .01 ), procedural justice has a significant negative effect on trust (coefficient $=\beta=-0.21 ; \rho<.01$ ), and interactional justice has an insignificant effect on trust (coefficient $=\beta=0.08 ; \rho=0.24$ ). Distributive justice has an insignificant effect on WOM (coefficient $=\beta=0.15 ; \rho=0.08$ ), procedural justice has an insignificant effect on WOM (coefficient $=\beta=0.02 ; \rho=0.44$ ), and interactional justice has an insignificant effect on WOM (coefficient $=\beta=-0.06 ; \rho=0.28$ ). The calculations can be summarized, see Table 3 .

The effect of the variable of distributive justice (DJ) on trust mediated by students' satisfaction in the excellent university can be summarized, see Table 4.

The summary of analysis results of the direct influence for each category of university (Excellent, Flagship, and Non-Flagship) can be seen in Table 5 .

From Table 5, the similarities of each university can be explained as follows:

1. Ihe first similarity

In the 3 (three) categories of universities, Distributive Justice (DJ) variable has a significant positive effect on satisfaction. The similarity is related to the employees have

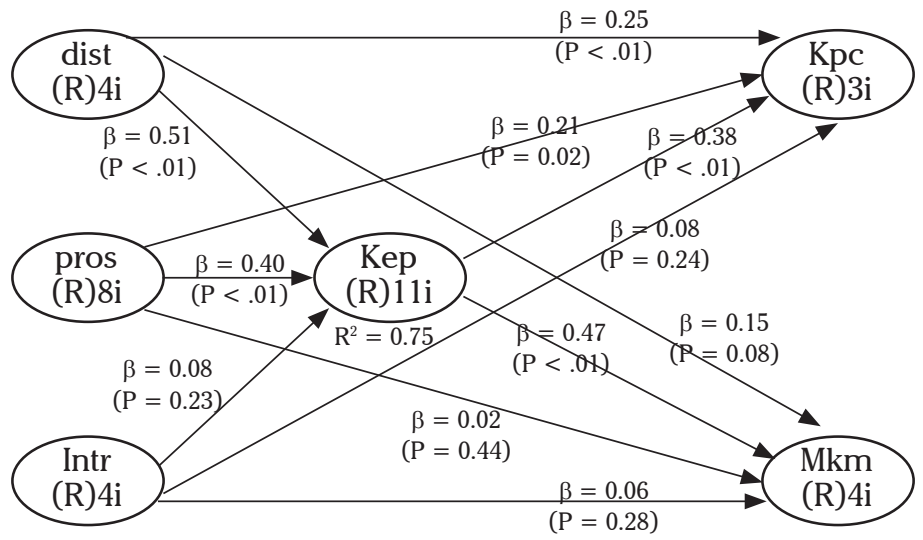

Figure 2. Full Model for Excellent University 
Table 3. The Direct Effect of the Variables of Distributive Justice (DJ), Procedural Justice (PJ) and Interactional Justice (IJ) on Satisfaction, Trust and WOM at University with Excellent Category

\begin{tabular}{|c|c|c|c|c|c|}
\hline Path & & & Coefficient & Probability & Conclusion \\
\hline DJ & $\longrightarrow$ & Satisfaction & $\beta=0.51$ & $(\rho<.01)$ & Significant Positive Effect \\
\hline PJ & $\longrightarrow$ & Satisfaction & $\beta=.-0.40$ & $(\rho<.01)$ & Significant Negative Effect \\
\hline $\mathrm{IJ}$ & $\longrightarrow$ & Satisfaction & $\beta=.0 .08$ & $(\rho=0,23)$ & Insignificant Effect \\
\hline DJ & $\longrightarrow$ & Trust & $\beta=.0 .25$ & $(\rho<.01)$ & Significant Positive Effect \\
\hline PJ & $\longrightarrow$ & Trust & $\beta=-0.21$ & $(\rho=0.02)$ & Significant Negative Effect \\
\hline $\mathrm{IJ}$ & $\longrightarrow$ & Trust & $\beta=.0 .08$ & $(\rho=0.24)$ & Insignificant Effect \\
\hline DJ & $\longrightarrow$ & WOM & $\beta=.0 .15$ & $(\rho=0.08)$ & Insignificant Effect \\
\hline $\mathrm{PJ}$ & $\longrightarrow$ & WOM & $\beta=.0 .02$ & $(\rho=0.44)$ & Insignificant Effect \\
\hline $\mathrm{IJ}$ & $\longrightarrow$ & WOM & $\beta=.-0.06$ & $(\rho=0.28)$ & Insignificant Negative Effect \\
\hline
\end{tabular}

Source: Research result

Table 4. The Indirect Effect of the Variables of Distributive Justice (DJ), Procedural Justice (PJ) and Interactional Justice (IJ) on Trust and WOM mediated by Satisfaction Variable at University with Excellent Category

\begin{tabular}{llll}
\hline Path & Coefficient & Coefficient & Conclusion \\
\hline DJ-Satisfaction-Trust & $\begin{array}{l}\mathrm{K}=0.51 ; \\
\mathrm{p}<0.01\end{array}$ & $\begin{array}{l}\mathrm{K}=0.38 ; \\
\mathrm{p}=<0.01\end{array}$ & $\begin{array}{l}\text { Supporting the hypothesis. Satisfaction mediates the } \\
\text { relationship between DJ and Trust }\end{array}$ \\
\hline DJ-Satisfaction-WOM & $\mathrm{K}=0.51 ;$ & $\mathrm{K}=0,47 ;$ & $\begin{array}{l}\text { Supporting the hypothesis. Satisfaction mediates the } \\
\mathrm{p}<0.01\end{array}$ \\
\hline relationship between DJ and WOM
\end{tabular}

Source: Research result

treated the students fairly and the employees have given satisfactory compensation in accordance with the student expectations.

\section{The second similarity}

In the 3 (three) categories of universities, Distributive Justice (DJ) variable has a significant positive effect on trust. The similarity is related to the employees have given adequate attention to the customer when service delivery errors occur; the employees have a very good attitude towards students when handling service error complaints; the employees are communicative when handling student complaints; the employees respect students when dealing with complaints that ultimately increase trust in all students. This aspect is worth noting because, from the respondent's answer, the complaint addressed is mostly to employees and section head. It means that the aspects of the complaint's focus are matters relating 
Table 5. The Direct Effect of the Variables of Distributive Justice (DJ), Procedural Justice (PJ) and Interactional Justice (IJ) on Satisfaction, Trust and WOM in each Category of University

\begin{tabular}{llll}
\hline PATH & \multicolumn{1}{c}{$\begin{array}{c}\text { University } \\
\text { with Excellent Category }\end{array}$} & \multicolumn{1}{c}{$\begin{array}{c}\text { University } \\
\text { with Flagship Category }\end{array}$} & $\begin{array}{c}\text { University } \\
\text { with Non-Flagship } \\
\text { Category }\end{array}$ \\
\hline DJ $\rightarrow$ Satisfaction & Significant positive effect & Significant positive effect & Significant positive effect \\
\hline PJ $\rightarrow$ Satisfaction & Significant negative effect & Negative effect & Significant positive effect \\
\hline $\mathrm{IJ} \rightarrow$ Satisfaction & Insignificant Effect & Significant positive effect & Insignificant effect \\
\hline DJ $\rightarrow$ Trust & Significant positive effect & Significant positive effect & Significant positive effect \\
\hline PJ $\rightarrow$ Trust & Significant negative effect & Negative effect & Negative effect \\
\hline IJ $\rightarrow$ Trust & Insignificant effect & Insignificant effect & Significant positive effect \\
\hline DJ $\rightarrow$ WOM & Insignificant effect & Significant positive effect & Significant positive effect \\
\hline PJ $\rightarrow$ WOM & Insignificant effect & Significant negative effect & Significant positive effect \\
\hline IJ $\rightarrow$ WOM & Negative effect & Significant positive effect & Insignificant effect \\
\hline
\end{tabular}

Source: Research result

to service and operations at lower levels. The students still have the trust because there are bosses (leaders) who can lead to the process of continuous improvement.

\section{The third similarity}

In the 3 (three) categories of universities: Procedural Justice (PJ) variable has a negative effect on trust. This means that although the students are given the opportunity to explain the complaints, to whom they must submit the complaints, and the process of their complaints can be quickly accessed, it does not necessarily give a positive impression of their trust to the existing procedural justice. From some open responses, it is found that they a sense of distrust to the person in which they have submitted the complaint. And they find that the complaints are not conveyed directly to the decision maker.

\section{The fourth similarity}

There are 2 (two) categories of universities where Procedural Justice (PJ) variable has negative effect on satisfaction, that is, in the excellent university category and flagship university category. This finding is interesting because these 2 (two) categories of universities, in terms of procedure, should be better than in the non-flagship university category. This means that if the perceived procedural justice increases, the student satisfaction will decrease and vice versa. The real phenomenon that the researcher perceives when interviewing is that this aspect is often conveyed to management but the response they get is very disappointing. So, even if there are changes and improvements in the procedural dimensions, the results cannot give satisfaction to the students.

\section{The fifth similarity}

There are 2 (two) categories of universities, where Interactional Justice (IJ) variable has no significant effect on trust, that is, in the excellent university category and in the flagship university category. These findings are interesting because they should have better interactional justice than in the non-flagship university category. This means that the interaction that has become the institution's policy has no effect on the trust of the students. From the interviews conducted by the researcher, it is obtained a picture that students often find the interaction and attitude of employees / employees that are less friendly. And the em- 
ployees sometimes ignored the students who are expressing complaint. The students have found it not just once but several times, and this is what makes them disappointed. So, even though there are changes and improvements in interactional dimensions, the results have not been able to create the student trust.

\section{The sixth similarity}

There are 2 (two) categories of universities where the Distributive Justice (DJ) variable has a significant positive effect on WOM (flagship and non-flagship university). It can be concluded that the indicators of distributive justice are related to the employees have given adequate attention to the customer when the errors in service delivery occur; the employees have a very good attitude towards students when handling service error complaints; the employees are communicative when handling student complaints; the employees respect students when handling complaints that ultimately can increase the student trust and WOM.

The summary of analysis results of the indirect effect for each category of university (excellent, flagship, and non-flagship) can be seen in Table 6 .

From Table 6, it can be concluded that the indirect effects that have similarities are as follows:

\section{The first similarity}

In the 3 (three) categories of universities, the variable of distributive justice (DJ) has an effect on WOM mediated by satisfaction. This result is consistent with the previous research. Tax and Brown (2000) find that distributive justice is the dominant reference in service recovery analysis.

\section{The second similarity}

In the 3 (three) categories of universities, the variable of satisfaction does not mediate the relationship between procedural justice (PJ) and trust. This result does not support the hypothesis.

\section{The third similarity}

In the 3 (three) categories of universities, the variable of satisfaction does not mediate the relationship between interactional justice (IJ) and trust. This result does not support the hypothesis.

\section{The fourth similarity}

In the 3 (three) categories of universities, the variable of satisfaction does not mediate the relationship between interactional justice (IJ) and WOM. This result does not support the hypothesis.

\section{The fifth Similarity}

In the excellent and flagship universities, the variable of satisfaction mediates the relationship between distributive justice (DJ) and trust. This result supports the hypothesis, but only in the non-flagship university that does not support the hypothesis.

\section{The sixth similarity}

In the top and flagship-categories universities, the variable satisfaction does not mediate the relationship between procedural justice (PJ) and WOM. This result does not support the hypothesis, but only in the non-flagship university that supports the hypothesis.

\section{MANAGERIAL IMPLICATIONS}

\section{Methodological Implication}

This research was conducted using simple but structured method and assisted by statistical test through validity test and reliability test procedures. The results of this study are expected to provide indepth understanding to further researchers as the source of consideration in designing the research methods to test the models to be observed.

\section{Research implication}

This study is expected to improve the researchers' 
Table 6. The Indirect Effect of the Variables of Distributive Justice (DJ), Procedural Justice (PJ) and Interactional Justice on Trust and WOM mediated by Satisfaction.

\begin{tabular}{|c|c|c|c|}
\hline PATH & $\begin{array}{c}\text { University } \\
\text { with Excellent Category }\end{array}$ & $\begin{array}{c}\text { University } \\
\text { with Flagship Category }\end{array}$ & $\begin{array}{c}\text { University } \\
\text { with Non-Flagship Category }\end{array}$ \\
\hline $\begin{array}{l}\text { DJ - Satisfaction } \\
\text { - Trust }\end{array}$ & $\begin{array}{l}\text { Supporting the hypothesis. } \\
\text { Satisfaction mediates the } \\
\text { relationship between DJ and } \\
\text { Trust. } \\
\mathrm{K}=0.51 ; \mathrm{p}<0.01 \\
\mathrm{~K}=0.38 ; \mathrm{p}=<0.01\end{array}$ & $\begin{array}{l}\text { Supporting the hypothesis. } \\
\text { Satisfaction mediates the } \\
\text { relationship between DJ and } \\
\text { Trust. } \\
\mathrm{K}=0.51 ;(\rho<.01) \\
\mathrm{K}=-0.38 ; \mathrm{p}=<.01\end{array}$ & $\begin{array}{l}\text { Not supporting the } \\
\text { hypothesis. Satisfaction does } \\
\text { not mediate the relationship } \\
\text { between DJ and Trust. } \\
\mathrm{K}=0.42 ;(\rho<.01) \\
\mathrm{K}=0.10 ; \mathrm{p}=0.17\end{array}$ \\
\hline $\begin{array}{l}\text { DJ - Satisfaction - } \\
\text { WOM }\end{array}$ & $\begin{array}{l}\text { Supporting the hypothesis. } \\
\text { Satisfaction mediates the } \\
\text { relationship between DJ and } \\
\text { WOM. } \\
\mathrm{K}=0.51 ; \mathrm{p}<0.01 \\
\mathrm{~K}=0,47 ; \mathrm{p}<.01\end{array}$ & $\begin{array}{l}\text { Supporting the hypothesis. } \\
\text { Satisfaction mediates the } \\
\text { relationship between DJ and } \\
\text { WOM. } \\
\mathrm{K}=0.51 ; \mathrm{p}<.01 \\
\mathrm{~K}=0.47 ; \mathrm{p}<.01\end{array}$ & $\begin{array}{l}\text { Supporting the hypothesis. } \\
\text { Satisfaction mediates the } \\
\text { relationship between DJ and } \\
\text { WOM. } \\
\mathrm{K}=0.42 ; \mathrm{p}<.01 \\
\mathrm{~K}=0.30 ; \mathrm{p}<.01\end{array}$ \\
\hline $\begin{array}{l}\text { PJ - Satisfaction } \\
\text { - Trust }\end{array}$ & $\begin{array}{l}\text { Not supporting the } \\
\text { hypothesis. Satisfaction does } \\
\text { not mediate the relationship } \\
\text { between PJ and Trust. } \\
\mathrm{K}=-0.40 ; \mathrm{p}<0.01 \\
\mathrm{~K}=0.38 ; \mathrm{p}=<0.01\end{array}$ & $\begin{array}{l}\text { Not supporting the } \\
\text { hypothesis. Satisfaction does } \\
\text { not mediate the relationship } \\
\text { between PJ and Trust } \\
\mathrm{K}=-0.40 ; \mathrm{p}<.01 \\
\mathrm{~K}=0.38 ; \mathrm{p}=<0.01\end{array}$ & $\begin{array}{l}\text { Not supporting the } \\
\text { hypothesis. Satisfaction does } \\
\text { not mediate the relationship } \\
\text { between } P J \text { and Trust } \\
K=0.27 ; p<.01 \\
K=0.10 ; p=0.17\end{array}$ \\
\hline $\begin{array}{l}\text { PJ - Satisfaction - } \\
\text { WOM }\end{array}$ & $\begin{array}{l}\text { Not supporting the } \\
\text { hypothesis. Satisfaction does } \\
\text { not mediate the relationship } \\
\text { between PJ and WOM } \\
\mathrm{K}=-0.40 ; \mathrm{p}<0.01 \\
\mathrm{~K}=0,47 ; \mathrm{p}<.01\end{array}$ & $\begin{array}{l}\text { Not supporting the } \\
\text { hypothesis. Satisfaction does } \\
\text { not mediate the relationship } \\
\text { between } \mathrm{PJ} \text { and WOM. } \\
\mathrm{K}=-0.40 ; \mathrm{p}<.01 \\
\mathrm{~K}=0.47 ; \mathrm{p}<.01\end{array}$ & $\begin{array}{l}\text { Supporting the hypothesis. } \\
\text { Satisfaction mediates the } \\
\text { relationship between PJ and } \\
\text { WOM } \\
\mathrm{K}=0.27 ; \mathrm{p}<.01 \\
\mathrm{~K}=0.30 ; \mathrm{p}<.01\end{array}$ \\
\hline $\begin{array}{l}\text { IJ - Satisfaction - } \\
\text { Trust }\end{array}$ & $\begin{array}{l}\text { Not supporting the } \\
\text { hypothesis. Satisfaction does } \\
\text { not mediate the relationship } \\
\text { between IJ and Trust } \\
\mathrm{K}=0.08 ; \mathrm{p}=0.23 \\
\mathrm{~K}=0.38 ; \mathrm{p}<0.01\end{array}$ & $\begin{array}{l}\text { Not supporting the } \\
\text { hypothesis. Satisfaction does } \\
\text { not mediate the relationship } \\
\text { between IJ and Trust } \\
\mathrm{K}=0.08 ; \mathrm{p}=0.23 \\
\mathrm{~K}=0.38 ; \mathrm{p}<.01\end{array}$ & $\begin{array}{l}\text { Not supporting the } \\
\text { hypothesis. Satisfaction does } \\
\text { not mediate the relationship } \\
\text { between IJ and Trust } \\
\mathrm{K}=0.14 ; p=0.09 \\
\mathrm{~K}=0.10 ; p=0.17\end{array}$ \\
\hline $\begin{array}{l}\text { IJ - Satisfaction - } \\
\text { WOM }\end{array}$ & $\begin{array}{l}\text { Not supporting the } \\
\text { hypothesis. Satisfaction does } \\
\text { not mediate the relationship } \\
\text { between IJ and WON } \\
\text { because IJ has no effect } \\
\text { on satisfaction, although } \\
\text { satisfaction has an effect on } \\
\text { WOM } \\
\mathrm{K}=0.08 ; \mathrm{p}=0.23 \\
\mathrm{~K}=0.47 ; \mathrm{p}<0.01\end{array}$ & $\begin{array}{l}\text { Not supporting the } \\
\text { hypothesis. Satisfaction does } \\
\text { not mediate the relationship } \\
\text { between IJ and WON } \\
\mathrm{K}=0.08 ; \mathrm{p}=0.23 \\
\mathrm{~K}=0.47 ; \mathrm{p}<0.01\end{array}$ & $\begin{array}{l}\text { Not supporting the } \\
\text { hypothesis. Satisfaction does } \\
\text { not mediate the relationship } \\
\text { between IJ and WON } \\
K=0.14 ; p=0.09 \\
K=0.30 ; p<.01\end{array}$ \\
\hline
\end{tabular}

Source: Research result

understanding related to service recovery for the students' satisfaction, trust and WOM in each category of university. The understanding on the variations found in this study provides different perspectives from previous research, such as by Singh and Pandya, 1991; Gustaffson, 2009; Mattila 
2001; Lin, Hsin-Hui, Wang, Yi-Shun and Chang, LiKuan, 2011; Nguyen, etal, 2012; Baker, Thomas and Mayer, Tracy, 2015, Moliner-Velazquez, et.al, 2015. These variations can be seen from the variables observed and the research objects of various categories of universities in Indonesia using the same instruments. This research is also expected to be a source of discussion and ultimately can be developed and tested again in different research settings in the future.

\section{University Managers}

The results of this study provide a deep understanding for university managers that the recovery of service to students has always been the focus of attention. It is evidenced at two universities that service recovery has insignificant effect either directly or indirectly on satisfaction, trust and word of mouth. The students' weak bargaining position makes the students communicate negatively to other parties, and this is very detrimental to the university.

Based on the results and conclusions described above, some suggestions can be put forward as follows:

1. The excellent university should manage its procedural justice and interactional justice well because they have an insignificant and even negative effect on satisfaction, trust and WOM.

2. The flagship university should manage its procedural justice because it has an insignificant effect on satisfaction, trust and WOM.

3. The non-flagship university should manage its interactional justice because it has an insignificant effect on satisfaction and WOM. A good interactional justice management will increase student's satisfaction which, in turn, will also increase student's WOM.

4. Through in-depth investigation, it is found that the students perceive that they have a low bargaining position and they feel "threatened" psychologically if they are too critical in complaining about the university policies. The university should capture this reality and make a student as a partner, not as an object of exploitation that harms many students.

5. Further research should include other variables in the model because based on the results of the analysis conducted, the contribution of the variables of distributive justice, procedural justice and interactional justice in influencing satisfaction is very small. The variable put forward is service quality.

In this study, the characteristics of the respondents and their correlation with satisfaction are not much discussed, therefore it is suggested that future research also test the satisfaction based on the respondents' characteristics, such as educational background, parent's income, the origin of the student, and even gender.

\section{CONCLUSION}

Service recovery models for the students' satisfaction, trust and WOM in each level of category of private universities in East Java are as follows:

1. In the university with excellent category, distributive justice (DJ) has a positive effect on students' satisfaction and trust, but has insignificant effect on WOM. Meanwhile, procedural justice (PJ) has an insignificant and negative effect on satisfaction, trust and WOM. Likewise, interactional justice (IJ) has insignificant effect on students' satisfaction, trust and WOM.

2. In the university with flagship category, satisfaction mediates the relationship between distributive justice (DJ) and trust. Satisfaction mediates the relationship between distributive justice (DJ) and WOM, but satisfaction does not mediate the relationship between procedural justice (PJ) and trust. Satisfaction does not mediate the relationship between procedural justice (PJ) and WOM. Satisfaction does not mediate the relationship between interactional justice (IJ) and trust. Satisfaction also does not mediate 
the relationship between interactional justice and WOM.

3. In the university with non-flagship category, satisfaction has a significant positive effect on trust. In addition, satisfaction also has a positive effect on WOM.

4. In the university with flagship category, distributive justice (DJ) has a positive effect on students' satisfaction, trust and WOM, but procedural justice (PJ) has a negative effect on students' satisfaction, trust and WOM. However, interactional justice (IJ) has a positive effect on students' satisfaction and WOM but has insignificant effect on trust.

5. In the university with flagship category, satisfaction mediates the relationship between distributive justice (DJ) and trust. Satisfaction mediates the relationship between distributive justice (DJ) and WOM. However, satisfaction does not mediate the relationship between procedural justice (PJ) and trust. Likewise, satisfaction does not mediate the relationship between procedural justice (PJ) and WOM. The difference is that satisfaction mediates the relationship between interactional justice (IJ) and trust. Similarly, satisfaction mediates the relationship between interactional justice (IJ) and WOM.
6. In the university with flagship category, satisfaction has a positive effect on trust, and satisfaction has a positive effect on WOM.

7. In the university with non-flagship category, distributive justice (DJ) has a positive effect on students' satisfaction, trust and WOM. Likewise, procedural justice (PJ) has a positive effect on satisfaction and WOM but has no effect on trust. Interactional justice (IJ) has an insignificant effect on satisfaction and WOM, but has a positive effect on trust.

8. In the university with non-flagship category, satisfaction does not mediate the relationship between distributive justice and trust, but satisfaction mediates the relationship between distributive justice (DJ) and WOM. Satisfaction does not mediate the relationship between procedural justice and trust. Satisfaction even mediates the relationship between procedural justice (PJ) and WOM. Satisfaction does not mediate the relationship between interactional justice (IJ) and trust. Satisfaction does not mediate the relationship between interactional justice (IJ) and WOM.

In the university with non-flagship category, satisfaction has a positive effect on trust, and satisfaction has a positive effect on WOM

\section{Acknowledgement}

The researchers would like to express sincere gratitude to the Rector of STIE Perbanas Dr. Lutfi., SE., M.Fin, Chairman of the Center for Research and Community Service Dr. Rr. Irmani., M. Si, Rector and management of UMM (excellent University), UKP (Flagship University) and UTGS (Non-flagship University). 
Beatriz Moliner-Velázquez, María-Eugenia Ruiz-Molina, Teresa Fayos-Gardó, (2015). Satisfaction with service recovery: moderating effect of age in word-of-mouth. Journal of Consumer Marketing, Vol. 32 Issue: 6, pp.470 484, https://doi. org/10.1108/JCM-12-2014-1251.

Chistopher H. Lovelock dan Laurent K. Wright (2007). Manajemen Pemasaran Jasa. Alih Bahasa Agus Widyantoro, Cetakan Kedua, Jakarta, PT. INDEXS.

Dick, A.S. and Kunal Basu. (1994). Customer Loyalty: Toward an Integrated Conceptual Framework. Journal of the Academic of Marketing Science, Vol. 22 (2): 99-113.

De Matos, C. A., Carlos. A. V. R. and, Ricardo T. V, Valter A. V. (2009). Consumer Reaction to service failure and recovery: the moderating role of attitude toward complaining. Journal of Services Marketing, Vol.23, No. 7, pp.462-475.

Doan T. Nguyen, Janet R. McColl-Kennedy, Tracey S. Dagger. (2012). Matching service recovery solutions to customer recovery preferences. European Journal of Marketing, Vol. 46 Iss: 9, pp.1171 - 1194.

East R. (2000). Complaining as Planned Behavior. Psychology \& Marketing, Vol. 17 (12):1077-1095.

Gustaffson, Anders. (2009). Customer Satisfaction with Service Recovery. Journal of Business Research. Vol.62: 1220-1222 Gronroos, C. (1988). Service quality: the six criteria of good perceived service. Review of Business, Vol. 9, Winter, pp. $10-30$

Henning-Thurau, T., Langer, M. F., and Hansen, U.( 2001). Modeling and Managing Student Loyalty—an Approach Based on the Concept of Relationship Quality, Journal of Service Research, Vol. 3, No. 4, pp. 331-344.

Hsin-Hui Lin, Yi-Shun Wang, Li-Kuan Chang. (2011). Consumer responses to online retailer's service recovery after a service failure: A perspective of justice theory. Managing Service Quality: An International Journal, Vol. 21 Iss: 5, pp.511 - 534.

Hume, Margee and Gillian Sullivan Mort. (2008). The consequence of appraisal emotion, Service quality, perceived value and customer satisfaction on repurchase intent in the performing arts. Journal of Services Marketing. Pp. 170- 182.

Kementerian Koordinator Bidang Pembangunan Manusia dan Kebudayaan. (2015, January 9). Menristek dan Dikti Tindak Perguruan Tinggi yang Terima Mahasiswa Melebihi Kuota. Retrieved from Kemenkopmk website: https://www. kemenkopmk.go.id/artikel/menristek-dan-dikti-tindak-perguruan-tinggi-yang-terima-mahasiswa-melebihi-kuota.

Layanan Aspirasi dan Pengaduan Online Rakyat. (2013, October 11). Keluhan fasilitas pelayanan pendidikan dan program sarjana ekstensi di universitas jambi. Retrieved from LAPOR website: https://www.lapor.go.id/id/1106547/keluhanfasilitas-pelayanan-pendidikan-dan-program-sarjana-ekstensi-di-universitasjambi.html.

Protes Kebijakan Kampus, Mahasiswa UPB Berunjuk Rasa Bawa Keranda. (2015, January 28). Batamtoday.com. Retrieved from Batamtoday.com website: http://bintan.batamtoday.com/berita53110-Protes-Kebijakan-Kampus,-Mahasiswa-UPBBerunjuk-Rasa-Bawa-Keranda.html.

SPP di Unibraw Naik, Mahasiswa Protes. (2012, July 26). Kompas.com. Retrieved from Kompas website: http://edukasi. kompas.com/read/2012/07/26/17404077/SPP.di.Unibraw.Naik.Mahasiswa.Protes.

Kana, Any Agus. (2001). Mass Customization Sebuah Alternatif untuk meningkatkan kepuasan Pelanggan, Yogyakarta. Jurnal kompak, STIE YO.

Kelley, Douglas Hoffman, and Mark A. Davis. (1993). A Typology of Retail Failures and Recoveries. Journal of Retailing 69 (winter): 429-452

Kotler, Philip dan Kevin Lane Keller. (2009). Manajemen Pemasaran. Edisi Ketiga Belas Jilid 1. Jakarta: Erlangga.

Lovelock, C. (2001). Service Marketing: People, Technology and Strategy. 4th ed. Upper Saddle River, NJ: Prentice Hall International, Inc.

Mattilla, Anna S. (2001). The Effectiveness of Service Recovery in the Multi-Industry Setting. Journal of Service Marketing, Vol. 15. No. 7, pp. 583-596

McDougall, G.H., \& Levesque, T. (2000). Customer satisfaction with service: Putting perceived value into the equation. Journal of Services Marketing. 14(5), 392-410.

Mahfud Sholihin dan Dwi Ratmono. (2013). Analisis SEM-PLS dengan WarpPLS 3.0 Untuk hubungan nonlinier dalam penelitian sosial dan bisnis. Penerbit Andi Yogyakarta.

Min Zhang, Xujing Dai, Zhen He. (2015). An empirical investigation of service recovery Ine-retailing: An operations management perspective. Journal of Service Theory and Practice, Vol. 25 Iss: 3, pp.348 - 367

Parasuraman A, Zeithhaml V.A, Berry L.L. (1985). A conceptual model of service quality and its implication for future research. Journal of Marketing, Vol 49: 41-50.

Richard L. Oliver. (1980). A Cognitive Model of the Antecedents and Consequences of Satisfaction Decisions. Journal of Marketing Research. Vol. 17, No. 4. pp. 460-469.

Robert Johnston, Stefan Michel, (2008). Three outcomes of service recovery: Customer recovery, process recovery and employee recovery. International Journal of Operations \& Production Management, Vol. 28 Iss: 1, pp.79 - 99. 
Seider, Kathleen and Berry, Leonard L. (1998). Service Fainess: What it is and why it matters. Academy of Management Executive, Vol. 12. No. 2.

Singh, J. and Shefali Pandya. (1991). Exploring the Effect of Customer Dissatisfaction Levelon Complain Behaviors. European Journal of Marketing. Vol. 25 (9): 7-21

Tax, Stephen S., Brown, Stephen W., and Chandrasekaran. (1998). Customer Evaluation of Service Complaint Experiences: Implications for Relationship Marketing. Journal of Marketing, Vol. 62 (April).

Thomas Baker, Tracy Meyer , (2014). Explanation information and source in service recovery initiatives. Journal of Services Marketing, Vol. 28 Iss: 4, pp.311 - 318.

Tronvoll, B. (2011). Negative Emotions and Their Effect on Customer Complaint Behaviour. Journal of Service Management,Vol. 22, No. 1, pp. 111-134.

Zeithaml, V.A., Berry, L.L. and Parasuraman, A. (1993). The nature and determinants of customer expectations of services. Journal of Academy of Marketing Science, Vol. 21, Winter, pp. 31-46.

Zemke, R. (1999). Service recovery: turning oops into opportunity. in Zemke, R. And Woods, J. (Eds), Best Practices in Customer Service, AMA Publications, NewYork, NY, pp. 279-88. 